\section{Oksana Storchay}

Ph.D. in Fine Art, restorer of graphics, Researcher at the Department of Fine Arts and Crafts Rylsky Institute of Art Studies, Folklore and Ethnology of the National Academy of Sciences of Ukraine

\section{Оксана Сторчай}

реставратор творів графіки, науковий співробітник віААіку образотворчого та Аекоративно-прикладного мистецтва Інституту мистецтвознавства, фольклористики та етнології ім. М. Т. Рильського

e-mail: storchai_ov@ukr.net orcid.org/0000-0003-0461-2816

\title{
Sacral Painting by Mikhail Vrubel: Problem of Canon (Kyiv Period Of Creative Activity)
}

\author{
Сакрамьний живопис Михайла Врубемя: \\ Проблема канону (київський період творчості)
}

\begin{abstract}
This article considers sacral painting by Mikhail Vrubel (1856-1910), a well-known Russian artist of Polish descent (on his father's side) during so-called "Kyiv period" (1884-1889). This period is one of the most important in Mikhail Vrubel's creative activity, when not only the main themes were determined and unique Vrubel's style was developed but a number of outstanding sacred monumental works were made. This paper studies Mikhail Vrubel's sacral painting in the context of canon and typical features of Russian church painting of the second half of the $19^{\text {th }}$ century.

Keywords: Kyiv period of Mikhail Vrubel's creativity, sacral paintings, problem of cannon.
\end{abstract}

Problem statement. Sacral painting of M. Vrubel is studied in this article in the context of canon and typical features of Russian church painting of the $2^{\text {nd }}$ half of the $19^{\text {th }}$ century. After careful study of two main directions that were established in church painting in Russian Empire by the end of the $19^{\text {th }}$ century, i.e. neo-Russian style and Art Nouveau, the author notes a particular role of Vrubel in the formation of the later. The article traces how Vrubel during Kiev period worked out the style of painting, which has been an integral part of the European version of Art Nouveau, through careful study of ancient Old Russ art of the $11^{\text {th }}$ century, Byzantine monumental art of $6-12^{\text {th }}$ centuries, Italian Renaissance painting and due to a special personal worldview. Influence of Western European religious art on Vrubel's work was also under study, particularly his sketches for St. Volodymyr's Cathedral.

Analysis of recent research works and publications. Sacral art of this outstanding artist has long been successfully studied in Russian and Ukrainian art criticism. S. Yaremich [27], D. Kogan [9], N. Dmitrieva [3, 4], A. Ivanov [8], D. Sarabyanov [23], as well as Kyiv researches K. Ladizhenska [11], O. Drug [5], I. Margolina [12, 13, 14, $15,16]$, N. Ageyeva [1, 7], A. Iling [7], V. Ulyanovsky [16, 25], N. Prakhov [21] V. Zummerr [6] and many others art critics studied his creative activity. The epistolary heritage of the artist was used in order to study the issue, specifically the book "Vrubel. Correspondence. Memoirs about the artist", which is still one of the best collections of materials to study creative heritage of M. Vrubel [2]. Present article is based on this research and also on consultancy given by of N. Ageyeva, the leading researcher of the National Museum "Kyiv Gallery of Art” (former Kyiv National Museum of Russian Art).

Objectives of the study. Objectives of the paper are to analyse sacral paintings of M. Vrubel during the "Kyiv period" (1884-1889) and also analyse artist's perception of the church cannon.

Presentation of the main research material. Mikhail Vrubel (1856-1910) is justly called the founder of Art Nouveau and Symbolism in Russian art. The ancestors of the artist on his father's side, the male line, came from Prussian Poland, female line came from Warsaw (the Milkovskys), but his grandmother belonged to the Polish Confederation. Decembrist Bassargin was among his ancestors on his mother's side by the male line, and Mr. Krabbe, member of the Finland Seim, was his ancestor by the female line.

Vrubel influenced Russian and in Ukrainian religious painting of the late XIX - early XX centuries. He was gifted muralist but unfortunately he was not able to unleash his potential in this area. "Kyiv period", which lasted for five years (1884-1889), is the only period when artist worked as muralist.

Church painting by M. Vrubel is studied by scholars in several aspects. One aspect is the context of the characteristic features of Russian religious painting in second half of the $19^{\text {th }}$ century, especially the end of $19^{\text {th }}$ century when Church painting in Russian Empire had two main trends: 


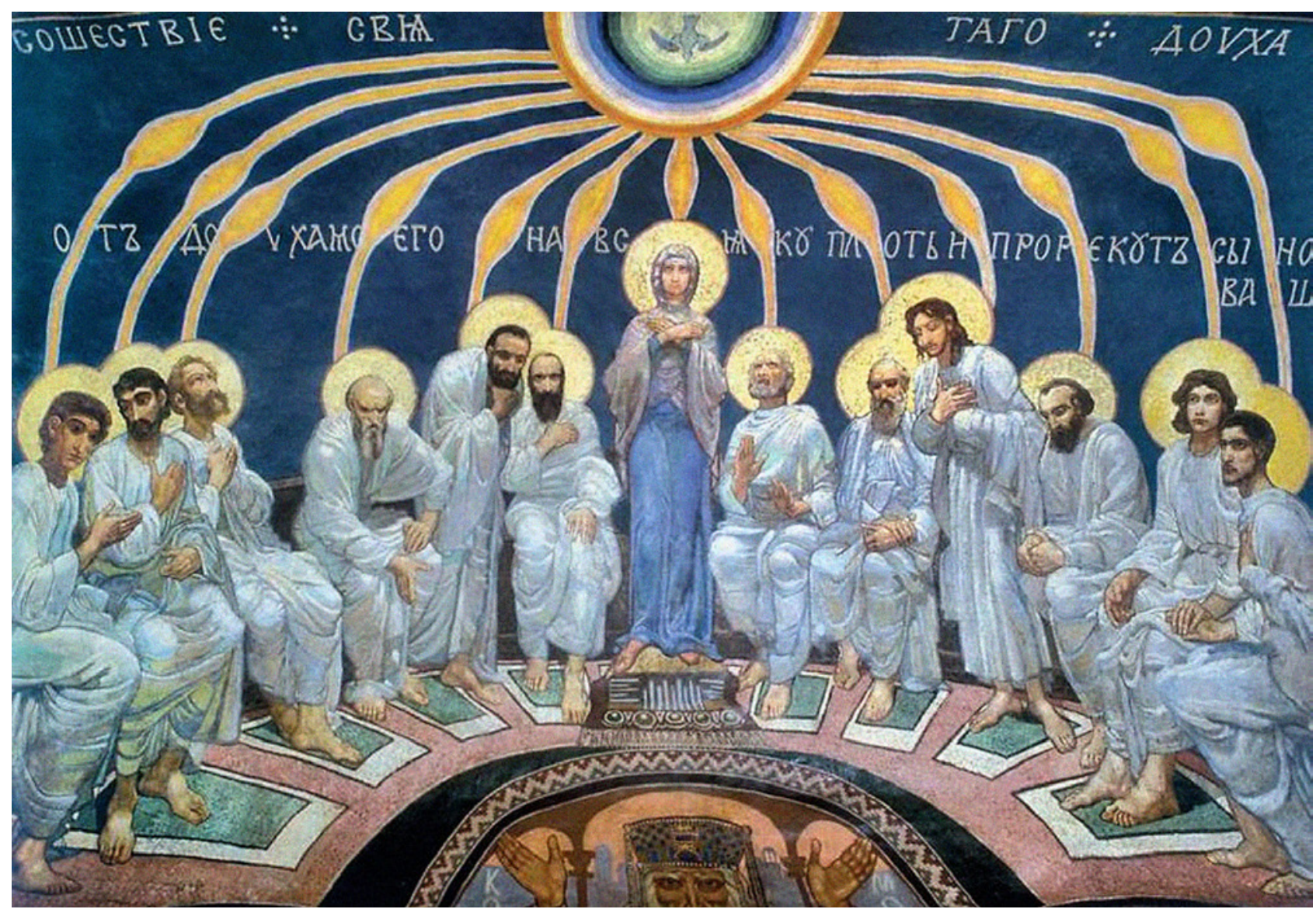

Vrubel M.A. The Descent of the Holy Spirit. 1884. Oil painting in the choir of St. Cyril's Church in Kiev

Neo-Russian Style (religious and national style) and Art Nouveau (New Style). The creative activity of M. Vrubel played an important role in the formation of these styles. Another aspect is the developing of his creative method. Through careful study of ancient artefacts (12 th century), Byzantine monumental art of $6-12^{\text {th }}$ centuries, and Italian Renaissance painting and due to personal worldview Vrubel produced his own style of painting during the "Kyiv period" which has become an integral part of European version of Art Nouveau. But the subject of canon in sacral paintings by the artist was little studied. However, taking into account small size of present paper and the fact that its specifics lies with popular science, we had only scratched the surface of the problem.

Kyiv period is defined not only by the main themes but also was the period during which a number of outstanding sacral monumental works were created. In 1884-1885 Vrubel made nine wall oil paintings in St. Cyril's Church in Kyiv: "The Archangel Gabriel”, "Entry into Jerusalem”, "Cloud Assumption", "Descent of the Holy Spirit upon the Apostles", "Head of Moses", "Head of the Prophet Solomon" "The Bust of Christ", "Angels with Labars", "Lamentation" /"Pieta" / and four images for the iconostasis of the church-Christ, the Virgin with Child, saint Cyril and saint Athanasius. Moreover, the artist recreated the lost images of angels in the dome of St. Sophia Cathedral in Kyiv in 1884-1885 and created picturesque composition "The Agony in the Garden" (1887) for the church in the estate of Y. Tarnowski in Motovilivka, village outside
Kyiv. Sketches for the painting of St. Vladimir's Cathedral in Kyiv, for which he made four versions of the composition "Lamentation" and two versions of "Resurrection" (1887) in watercolor played great role in forming of the artist's unique style.

We would like to remind that iconography is, in the most general terms, the system of rigid canons (templates, standards and techniques) of how to depict individual characters and scenes. In the middle of the XIX century the Orthodox Church designated the basic requirements for church painting: "in compliance with 'historical truth', idealizing images and baning such frivolity as depiction of "nude human body, exquisite poses, passionate glances, athletic forms without obvious need ..." [20] and expressed the need to distinguish the concepts of an icon and a painting on a religious theme, though the Church did not specify dogmatic and aesthetic differences between them. The government, on behalf of Grand Princes and Grand Princesses, who held the position of president of the Academy of Fine Arts, also managed Russian sacral art. With its support, vice-president of the Academy of Arts, Prince G. Gagarin established the class of Orthodox iconography at the Academy. The basis of the class curriculum, which was supervised by Professor T. Neff, was in strict adherence to patterns of "Byzantine art" that were taken from the ancient shrines of Kyiv, Novgorod, Suzdal, Vladimir, churches in Georgia and the Caucasus and in the territories where Orthodox culture was spread, in Greece, Italy and on Mount Athos. 


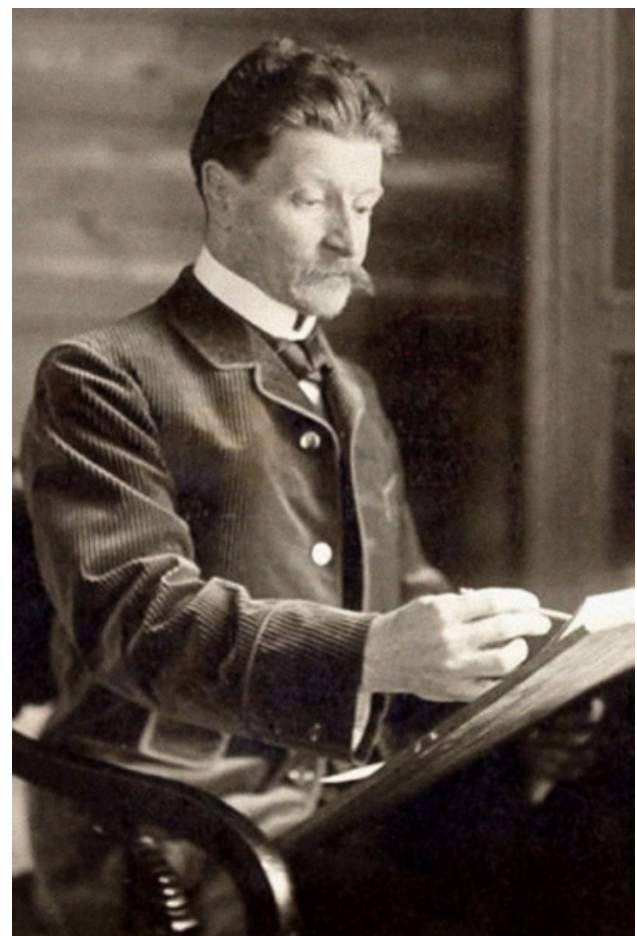

Mikhail Vrubel. Photo

But professors of the Academy opposed the idea of Orthodox iconography class. They believed that "imitation of Byzantine painting will lead to the decline of painting in Russia and that the requirement for conventional types of icons will never develop a talent" [20]. The Class of Orthodox iconography was short-lived, from 1856 to 1859. In addition to his duties as vice-President, Prince Gagarin was personally involved in the church painting project. The painting created by him in the church of the Mariinsky Palace in St. Petersburg (1856) became the intermediate link between classicism of the early $19^{\text {th }}$ century and national religious style in art that was fully developed only at the end of the century.

In ancient Russia picturesque location of scenes in the church was determined by cosmic and topographic features, architectural forms and dogmatic purposes. At the end of the XIX century order of significance of elements in canonical triad "God-likeness_ethics - aesthetics" started to change. Aesthetics was put on the $1^{\text {st }}$ place, followed by ethics and God-likeness was last. The expression "to paint over the shrine/temple" was understood as "to decorate or arrange" and church painting instead of "visual theology" was limited to illustrations of the Holy Bible that satisfied aesthetic needs of Russian society at that period [20].

N. Pokrovski (1848-1917), well-known scholar and art historian, who, along with other scholars developed syllabus on painting for Orthodox churches that were under construction, deserves much of the credit for formation of religious and national style. His pictorial art projects included picturesque images of Jesus Christ, the Virgin Mary, saints and scenes from the Holy Bible according to the canon of scenes location in churches and numerous characters from the early Christian, Byzantine and Russian church history. Such decoration of churches contributed to the strengthening of religious feeling and promoted respect for national roots. The interior of an Orthodox church emphasised "the importance of the monument of Russian art" and implement "the ideal that would spiritualize the generation" [20]. This concept allowed the artists to develop the church canons and at the same time to preserve the spiritual meaning of icons, to change the form and "language" of the paintings and to create new iconography. This creative process was seen as a natural development of art. Thus, a new national and religious movement appeared.

Many artists of the second half of the $19^{\text {th }}$ century (V. Vasnetsov, N. Bodarevsky, M. Nesterov, N. Bruni etc.) developed their painting techniques and artistic language resulting in appearance of religious images-symbols. This system of rules and painting techniques can be described as special, individual artist's canon. Individual religious canon that reflects artist's views on the ideal of spiritual unearthy beauty can be found in the works by M. Vrubel.

The analysis of sacral compositions by $\mathrm{M}$. Vrubel shows clear how a talented and creative artist interprets themes of traditional church painting. For example, his paintings in the church of St. Cyril and St. Sophia Cathedral reflect an organic and in-depth understanding of Byzantine art and Old Russ art of the $12^{\text {th }}$ century reinterpreted by a man and an artist who lives in late $19^{\text {th }}$ century.

One of the most respected researchers of Art Nouveau D. Sarabyanov noted that the new trend was formed in line with national concepts. He noted that bias towards national issue "was characteristic to Art Nouveau in several European countries” [23, p. 79]. However, academic features are noticeable in Mikhail Vrubel's works. They are found in the tendency toward strict rules of art, focusing on beauty which is consciously selected as an object of creation. But Vrubel consistently overcame academism, reinterpreted nature, "rejected an alliance with naturalism which was typical for the late European academicism" [23, p. 81].

Let us briefly consider sacral works of Vrubel executed during "Kyiv period." The artist executed the most significant monumental works in St. Cyril's Church which can boast the world's largest ensemble of ancient frescos of the $12^{\text {th }}$ century that survived to present times. The vicinity of Vrubel's paintings to these monuments of religious art shows that the level of his talent is equal to that of ancient masters and we can see versatility of his talent. In 1884, while still a student of the St. Petersburg Academy of Arts, Vrubel accepted the offer of professor, philanthropist and art historian Adrian Prahov to participate in the restoration of St. Cyril's Church and execution of new compositions in situ of lost frescos of the 12 century that would organically fit into the interior of the ancient shrine. The new concept of A. Prahov's plan was obvious: "co-authorship" with the masters of the $12^{\text {th }}$ century which was new idea for prominent artists of the $19^{\text {th }}$ century. In the 1880s interest in national antiquity among experts and educated people increased though not from the point of view of artistic value but from the historical point of view. It was in St. Cyril's Church and St. Sophia Cathedral where for the first time Vrubel, and A. Prahov assisted him at that, 
Vrubel M.A. Lamentation. The third variant with the figure of the Virgin in the background. A sketch for an unrealized painting of the cathedral. 1887. Paper, black watercolor, pencil. National Museum "Kiev art gallery"

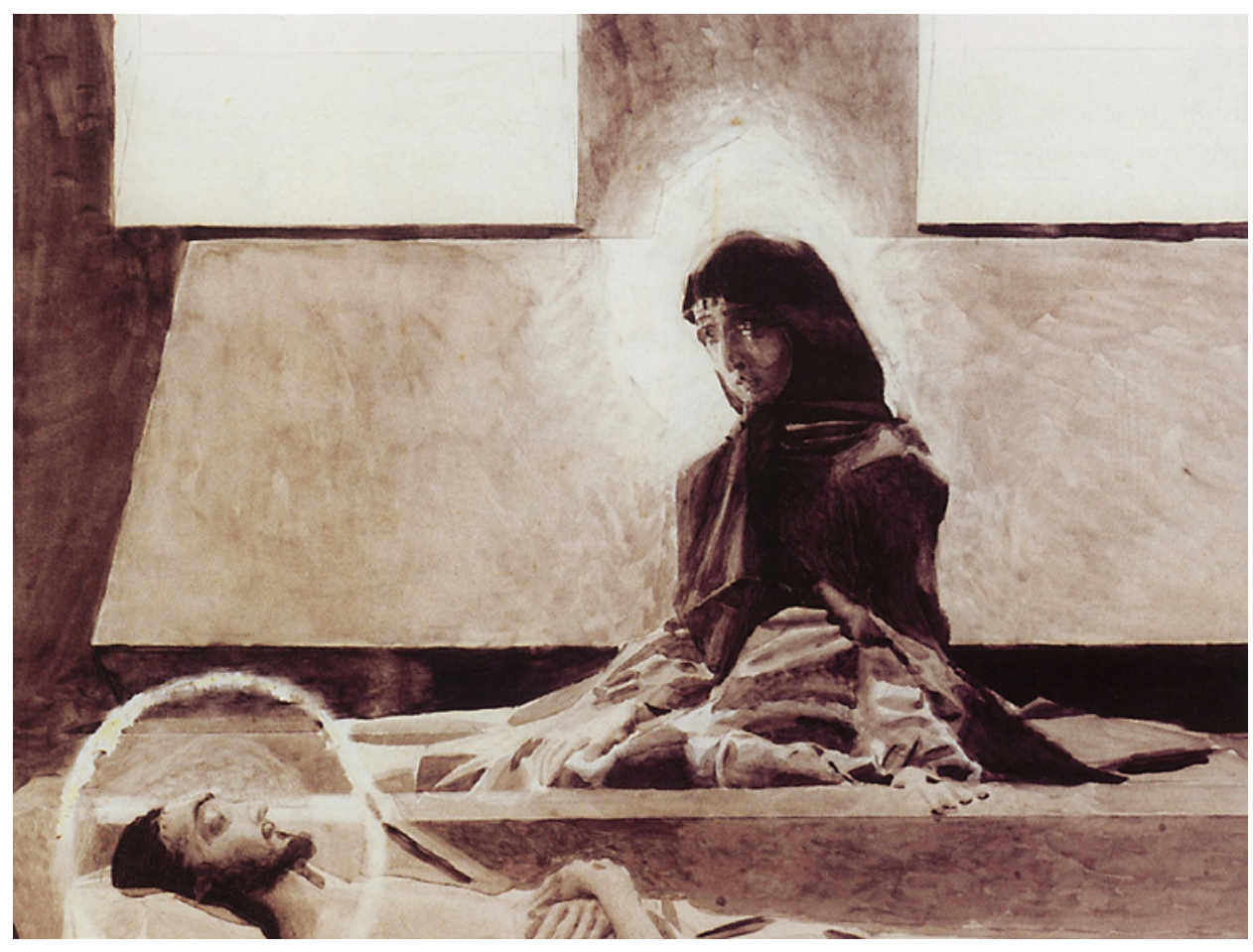

managed to achieve transition from archaeological research and restorations to live modern creativity and embrace great painting tradition of ancient Old Russ and Byzantine art and art of the Renaissance era.

Monumental works in the St. Cyril's Church created by M. Vrubel such as "The Archangel Gabriel” "Entry into Jerusalem”, “Cloud Assumption”, "Head of Moses”, "Head of the Prophet Solomon", "Bust of Christ”, "Angels with Labars" show, as it was mentioned above, the artist's deep understanding of Byzantine art and Old Russ art, ancient iconography and feeling of color. Most of the compositions are performed in accordance with the canon but still there are exceptions. In the story "Ascension" there is a retreat from the iconographic canon which was due to objective reasons; the composition is painted above the northern portal of the cathedral which was rebuilt at the time, it was expanded and increased in height. Due to this it was not possible to replicate the composition in accordance with the picture of the $12^{\text {th }}$ century. In the "Bust of Christ" the Messiah surprises with both inconsistency as to the accordance with the Christian canon and figurative description inherent to Vrubel which was the evidence of the creative search of the artist, gradual development of his system of painting techniques and rules, search of the individual canon. One of the main aspects of Vrubel's creative search was to understand, unravel and reveal the human soul.

One of the most significant works of Vrubel in St. Cyril's Church is "Descent of the Holy Spirit" at the choir. The artist conveyed the complexity of human emotions with extraordinary force in the images of the apostles; he created a gallery of portraits with deep psychological characteristic. He painted them from Kyiv intellectuals and clergy of that time: the priest of the church, Peter Orlovsky, archaeologist Goshkevich and Professor Prahov. It is remarkable that all of them were the brightest representatives of the intellectual elite of that time, well-known researchers and connoisseurs of Kyiv Christian antiquities and people of high spiritual culture. Young Apostle shown the third from the left side of Mary has undeniable resemblance to Vrubel himself. According to iconographic canons the Apostle Luke is always portrayed the third from the left side of the Virgin Mary. It is known that Luke was not only an apostle and evangelist but also a painter who made the first pictorial image of Holy Mother; in the Christian tradition he is regarded as the author of the famous icon of "Holy Mother of Vladimir". It is remarkable that Vrubel deliberately portrayed himself in the place of Luke, ie on the place of an icon painter. Vrubel uses a large range of colors that is why the garments of the saints seem to be of different colors in daylight, in the evening and in night light. Artistic synthesis of Christian, historical and symbolic perspective composition is manifested in changes in figurative space and the plastics of figures. Vrubel's individual manner is already vivid in this work, integral in its composition; features of Art Nouveau become heavily noticeable, they were manifested in laconic picturesque decision and especially in the heightened emotional images.

The composition ends with the image of King of the Universe. The Elder with a beautiful white beard, wearing a crown, adorned with precious stones, with uplifted hands to heaven as if he supports this great monumental composition. The symbolic image of the King of the Universe personifies dark, unenlightened part of humankind in Byzantine iconography to which apostles will bring light of Christian faith in different languages. And it is not accidentally that the open palms of King the Universe face the top of the composition. From God the Father, Jesus Christ, the Holy Spirit, through the enlightened apostles King of the Universe perceives divine grace converging in the form of flames of Pentecost by his palms open to the sky. Architectural details, contours of Gothic and Oriental houses resembling 
a minaret serve as background for the Elder. Characteristic buildings and structures from different geographical regions in different styles symbolize cardinal directions of the north, south, east and west. Apostles will go in these directions to carry Faith of Jesus Christ to the people. Vrubel created the icons of the iconostasis of St. Cyril's Church, Savior, the Virgin, Saints Cyril and Athanasius in 1884-1885 in Venice where he also studied mosaics and frescoes of old masters. The image of Holy Mother is executed especially gently and tenderly with eyes full of tears and expression of suffering for mankind on her face. One can feel here not only virtuosity but the depth of genuine religious experience. Without departing from the church canon the artist brings personal experiences and individual perception of Italian Renaissance painting to the image he created.

Vrubel's works in St. Sophia became an interesting experience in monumental sacral painting. A. Prahov revealed several mosaics in the dome drum, the images of Pantocrator, an archangel, the upper part of the figure of the Apostle Paul and ornaments. According to the tradition of Byzantine church four angels with Labaras were supposed to be in this place and they were to be directed to the four cardinal points and personifying the four seasons. Only one in the blue and dark blue robes representing "Winter" was preserved. A. Prahov proposed M. Vrubel to add the missing three angels. In line with the figure of the archangel preserved the artist performed the other three angels with slight modifications. Firstly he painted the robes in dense tones and after the paint dried, it seemed as if he laid out the robes in mosaic square stones of different hues. The artist made imitation of smalt a little bit bigger in size than the original smalt stones, he knew that stones painted on the surface with oil paint would not reflect light as well as the real mosaic stones that reflect light at different angles if the brush strokes were of the same size as the size of real smalt stones. And in these works Vrubel felt himself a participant of devoted work of old masters and tried to be worthy of them, he managed to find the really big tradition in painting and the laws of its expression.

The heritage of Vrubel's religious painting is divided into two parts: monumental and painting of the artist that were made or executed i.e. put into life and the second part consists of his works that remained only in sketches. Images for the iconostasis of the church in Motovilovka village near Kyiv ordered to Vrubel by Y. Tarnovski remained unfinished. The painting from the collection of the Kyiv National Museum of Russian Art "Agony in the Garden" (1887) gives an idea about unfulfilled intentions. The developing of the plot is typical for the second half for the XIX century. And according to contemporaries, influence of the famous artist N. Ge is quite noticeable. At the same time there are features of the late academism,. manifested in idealisation, even mild sweetness in appearance of the main evangelical character. Christ is depicted in profile with folded hands. The objective world in the picture is dematerialized. Nature, losing its texture and weight under cover of night begins transformation into its opposite-the world of shadows. Crown of thorns, a harbinger of death on the cross depicted on the canvas is not clear, it is ghostly, its contour is blurred. Artistic, pictorial language of the painting translated into the language of symbols that emphasize the illusory nature of all earthly things.

Watercolor sketches for painting of St. Vladimir's cathedral performed in 1887 in the estate of Y. Tarnowski near Kyiv became a further step towards gaining his own brushwork which is Russian variant of Art Nouveau for certain. The sketches that remained in watercolor (now they are preserved in the collection of the National Museum "Kyiv art gallery", former Kyiv National Museum of Russian Art) are focused on two subjects - "Lamentation" and "Resurrection."

Vrubel creates a sketch of "Resurrection" for the lateral northern chapel. In addition to the figure of Christ and the angels artist includes figures of sleeping warriors and flowers that filled the middle of the bottom of the picture (the flowers then turning into an ornament in the composition). Ornamentality is a characteristic feature of Vrubel's creative work and one of the hallmarks of Art Nouveau. The sketch was rejected by the construction committee which did not like the shape of the Roman guards that were placed by the artist directly on the ground. Despite this Vrubel continued to work on the sketches and created another version of the "Resurrection" and four variants for the composition "Lamentation." One sketch of "Lamentation" allows us to follow the search of the compositional solution that could express the tragedy event most accurately. In one of the variants made in the technique of black watercolor real space is transformed by the artist into the imaginary space. The figure of the Virgin and horizontally elongated lifeless body of the Savior make a tranquil cross shaped form slightly enriched by halos circles. The silhouette execution of the flattened volumes on the neutral background is also a characteristic of Art Nouveau. Stretched, slow passage of time is another important component of style in this sketch. By choosing the most tragic moment the artist halts time. It creates feeling of intense intermission that lasts forever. Great aesthetic value of watercolors lies not only in harmony and absolute unity of color, silhouettes and forms of the image but in the spiritual depth of each separate element of the form.

The sketches for the painting of the cathedral were not accepted for execution. At the same time they were highly appreciated by A. Prahov who opined that another church should be built for Vrubel's sketches. Indeed, Vrubel's sketches differed greatly from national religious style promoted by official Church and from the style which is artistically implemented in St. Vladimir's Cathedral in Kyiv; the sketches differed especially from the compositions by Vasnetsov. It was impossible to believe that Vrubel who perfectly handled the task of revival of ancient style in St. Cyril's Church would not have created the sketches for the church of St. Vladimir's Cathedral in the style ordered by the customers. Most likely it was high time for the individual painting style of the artist that was formed by that period to go on the air. The artist treated watercolor sketches as an independent works. "Do not think that these are templates only and not pure creativity," 
wrote M. Vrubel to his sister [2; 26]. Biblical and evangelical images accompanied the artist throughout all his creative life reflecting the beauty of the universe. Art Nouveau as a style of religious painting in Kyiv did not receive further artistic development. Religious and national style continued its dominance. M. Nesterov was one of the few Russian artists who continued the tradition of Art Nouveau in church painting (paintings in the church of Alexander Nevsky in Abastuman, 1898; Martha and Marymonastary in Moscow, 1908-1911).

Conclusions. Evaluating the millage covered by M. Vrubel as a muralist we can conclude that his creative work developed on the basis of academic forms of painting and naturally

\section{References}

1. Ageeva N.E. M.A. Vrubel. K istorii neosuschestvlyonnoy kartinyi na temu stihotvoreniya M. Yu. Lermontova "Angel" // Lermontovskie chteniya-2014: Cb. statey / avt. vstup. stati S. S. Sereychik; per. na angl. yaz. Sankt-Peterburg: Liki Rossii, 2015. S. 109-115.

2. Vrubel M. A. Pisma k sestre. Vospominaniya o hudozhnike Annyi Aleksandrovnyi Vrubel. Otryivki iz pisem ottsa hudozhnika / vstup. st. A. P. Ivanova. Leningrad: Izdatel Komitet populyarizatsii hudozhestvennyih izdaniy pri Gosudarstvennoy Akademii istorii materialnoy kulturyi, 1929. $208 \mathrm{~s}$.

3. Dmitrieva N. A. Mihail Vrubel. Zhizn i tvorchestvo. Moskva: Detskaya lit., 1984. 142 c.

4. Dmitrieva N.A. Mihail Aleksandrovich Vrubel. Leningrad: Hudozhnik RSFSR, 1990. $180 \mathrm{~s}$.

5. Druh O. Vrubel i Kyiv // Vrubel i Kyiv: Kataloh. Kyiv: Feniks, 2013 S. 10-19.

6. Zummer V.M. Vrubel v Kyrylivskii tserkvi // Yuvileinyi zbirnyk na poshanu akademika D. Y. Bahaliia. Kyiv, 1927. S. 425-438.

7. Illinh A., Aheieva N. Tvory M. O. Vrubelia v Kyivskomu natsionalnomu muzei rosiiskoho mystetstva // Vrubel i Kyiv: Kataloh. Kyiv: Feniks, 2013. S. 80-414.

8. Ivanov A. P. M.A. Vrubel. Leningrad: Gosudarstvennyiy russkiy muzey, 1928. 76, [4] s., il.

9. Kogan D.Z. M. A. Vrubel. Seriya: Zhizn v iskusstve. Moskva: Iskusstvo, 1980. 352 s., 32 l. ill.

10. Kravchenko N. I. Pravoslavna ikona i khrystyianska relihiina tematyka v sekuliarnomu obrazotvorchomu mystetstvi: Monohrafiia, Kyiv: Instytut humanitarnykh doslidzhen, 2004. S. 147-156.

11. Ladyzhenska K. Tvory M. O. Vrubelia v Kyivskomu natsionalnomu muzei rosiiskoho mystetstva // Vrubel i Kyiv: Kataloh. Kyiv: Feniks, 2013. S. 40-55.

12. Margolina I. Angelyi Vrubelya. Tvorchestvo Mihaila Vrubelya v Kirillovskoy tserkvi Kieva. Kiev: Gorobets, 2009. 56 s.

13. Marholina I. Zhyvopys M. O. Vrubelia v Kyrylivskii tserkvi Kyieva // Vrubel i Kyiv: Kataloh. Kyiv: Feniks, 2013. S. 22-36.

14. Marholina I. Kompozytsiia Mykhaila Vrubelia "Zishestia Sviatoho Dukha na apostoliv”: [Kyrylivska tserkva] // Pamiatky Ukrainy. 2013. \#2. S. 36-45.

15. Marholina I. Tvory M. O. Vrubelia v Kyrylivskii tserkvi ta Sofiiskomu sobori // Vrubel i Kyiv: Kataloh. Kyiv: Feniks, 2013 S. 58-74.

16. Marholina I. Ulianovskyi V. Kyivska obytel Sviatoho Kyryla: Monohrafiia, Kyiv: Lybid, 2005, 352 s.: il. evolved to Art Nouveau. And by his creative activity and even by his appearance he embodies the highest level of artistic achievements of high Art Nouveau and at the same time he preserves characteristic national features of $19^{\text {th }}$ century Russian art.

In the history of Ukrainian artistic culture of the late $19^{\text {th }}$ and early $20^{\text {th }}$ centuries, Mikhail Vrubel and his "Kyiv period" in particular occupy a special place. It is impossible to imagine the history of the national art without artist's monumental and easel paintings in St. Cyril Church, monumental paintings in St. Sophia Cathedral and sketches of the painting for St. Vladimir's Cathedral.

\section{Мітература}

1. Агеева Н.Е. М.А. Врубель. К истории неосуществлённой карти-

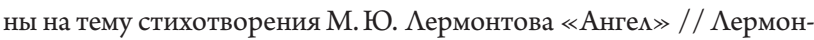
товские чтения-2014: Сб. статей / авт. вступ. статьи С. С. Серейчик; пер. на англ. яз. Санкт-Петербург: Аики России, 2015. С. 109-115.

2. Врубель М. А. Письма к сестре. Воспоминания о художнике Анны Александровны Врубель. Отрывки из писем отца художника / вступ. ст. А.П. Иванова. АенинграА: ИзАатель Комитет попумяризации художественных изданий при ГосуАарственной Академии истории материальной культуры, 1929. 208 с.

3. Амитриева Н.А. Михаил Врубель. Жизнь и творчество. Москва: Аетская пит., 1984. 142 с.

4. Амитриева Н.А. Михаил Александрович Врубель. АенинграА: Художник РСФСР, 1990. 180 с.

5. Аруг О. Врубель і Київ // Врубель і Київ: Каталог. Київ: Фенікс, 2013. C. 10-19.

6. Зуммер В.М. Врубель в Кирилівській церкві // Ювілейний збірник на пошану академіка А. Й. Багалія. Київ, 1927. С. 425-438.

7. Іллінг А., Агеєва Н. Твори М. О. Врубеля в Київському національному музеї російського мистецтва // Врубель і Київ: Каталог. Київ: Фенікс, 2013. С. 80-414.

8. Иванов А. П. М.А. Врубель. АенинграА: Государственный русский музей, 1928. 76, [4] с., ил.

9. Коган А. З. М.А. Врубель. Серия: Жизнь в искусстве. Москва: Искусство, 1980. 352 с., 32 м. имл.

10. Кравченко Н.І. Православна ікона і християнська релігійна тематика в секумярному образотворчому мистецтві: Монографія, Київ: Інститут гуманітарних досліАжень, 2004. С. 147-156.

11. Мадиженська К. Твори М. О. Врубеля в Київському національному музеї російського мистецтва / / Врубель і Київ: Каталог. Київ: Фенікс, 2013. С. 40-55.

12. Марголина И. Ангелы Врубемя. Творчество Михаила Врубеля в Киримловской церкви Киева. Киев: Горобец, 2009. 56 с.

13. Марголіна I. Живопис М. О. Врубеля в Кирилівській церкві Києва // Врубель і Київ: Каталог. Київ: Фенікс, 2013. С. 22-36.

14. Марголіна I. Композиція Михайла Врубеля «Зішестя Святого Ауха на апостолів»: [Кирилівська церква] // Пам'ятки України. 2013. № 2. C. 36-45.

15. Марголіна I. Твори М. О. Врубеля в Кирилівській церкві та Софійському соборі // Врубель і Київ: Каталог. Київ: Фенікс, 2013. C. 58-74.

16. Марголіна I. УАьяновський В. Київська обитель Святого Кирила: Монографія, Київ: АибіАь, 2005, 352 с.: іл. 
17. Martyinovskiy A. Ob ikonopisanii. URL: https://bit.ly/33G3FIC (access date: 06.13.2019).

18. Mihail Vrubel: Katalog. Iz sobraniya Russkogo muzeya, SanktPeterburg: Palace Editions, 2006. 132 s., 133 ill.

19. Murashko M. I. Spohady staroho vchytelia. Kyiv, 1964. S. 69-82.

20. Religiozno-natsionalnoe napravlenie v russkoy zhivopisi. Po materialam knigi: Gusakova V. O. Viktor Mihaylovich Vasnetsov i religiozno-natsionalnoe napravlenie v russkoy zhivopisi XIX — nachala HH veka. Sankt-Peterburg: Avrora, 2008. URL: http://ruskline.ru/ analitika/2011/02/05/religioznonacionalnoe_napravlenie_v_russkoj_zhivopisi/ (access date: 06.13.2019).

21. Prahov N. A. Stranitsyi proshlogo. Ocherki-vospominaniya o hudozhnikah / obsch. red. V.M. Lobanova. Kiev: Derzh. vid-vo obrazotvorchogo mistetstva I muzichnoYi lIt-ri URSR, 1958. S. 94-115.

22. Pronina M. Problemy identychnosti y tradytsii u monumentalnomu zhyvopysi Kyrylivskoi tserkvy KhII ta KhIKh st. na prykladi anhelskykh chyniv // Naukovi zapysky Natsionalnoho universytetu "Ostrozka akademiia”. Seriia: Kulturolohiia. 2013. Vyp. 13. S. 73-82. URL: http://nbuv.gov.ua/UJRN/Nznuoakl_2013_13_10 (access date: 06.13.2019).

23. Sarabyanov D. V. Stil modern. Istoki, istoriya, problemyi. Moskva: Iskusstvo, 1989. 293, [1] s., il.

24. Russkiy modern v ikonopisi. Sobor sv. ravnoapostolnogo knyazya Vladimira v Kieve. Kiev: Tipografiya S. Kulzhenko, 1905. VIII. 137 s. URL: Russkiy modern v ikonopisi. http://www.raruss.ru/ russe-moderne/3984-modernist-style-russian-icons.html (access date: 06.13.2019).

25. Ulianovskyi V. Dyvo y dyva kyivskoho Volodymyrskoho soboru. Kyiv: Lybid, 2016. 432 s.: il.

26. Kogan D.Z. Vrubel. URL: https://www.litmir.me/br/?b= 200516\&p=32 (access date: 06.13.2019).

27. Yaremich S. Ya. Mihail Aleksandrovich Vrubel: Zhizn i tvorchestvo Moskva: Izdanie I. Knebel, 1911. 208 s.
17. Мартыновский А. Об иконописании. URL: https://bit. ly/33G3FIC (Аата обращения: 13.06.2019).

18. Михаил Врубель: Каталог. Из собрания Русского музея, СанктПетербург: Palace Editions, 2006. 132 с., 133 имм.

19. Мурашко М. I. Спогади старого вчитемя. Київ, 1964. С. 69-82.

20. Религиозно-национальное направление в русской живописи. По материалам книги: Гусакова В.О. Виктор Михайлович Васнецов и религиозно-национальное направление в русской живописи XIX — начама XX века. Санкт-Петербург: Аврора, 2008. URL: http://ruskline.ru/analitika/2011/02/05/religioznonacionalnoe_ napravlenie_v_russkoj_zhivopisi/ (Аата обращения: 13.06.2019).

21. Прахов Н.А. Страницы прошлого. Очерки-воспоминания о хуАожниках / общ. реА. В. М. Аобанова. Киев: Аерж. виА-во образотворчого мистецтва і музичної ніт-ри УРСР, 1958. С. 94-115.

22. Проніна М. Проблеми іАентичності й традиції у монументальному живописі Кирилівської церкви XII та XIX ст. на прикладі ангельських чинів // Наукові записки Національного університету «Острозька академія». Серія: Кумьтурологія. 2013. Вип. 13. С. 7382. URL: http://nbuv.gov.ua/UJRN/Nznuoakl_2013_13_10 (Аата звернення: 13.06.2019).

23. Сарабьянов А. В. Стиль модерн. Истоки, история, проблемы. Москва: Искусство, 1989. 293, [1] с., ил.

24. Русский модерн в иконописи. Собор св. равноапостольного князя Владимира в Киеве. Киев: Типография С. Кульженко, 1905. VIII. 137 c. URL: Русский модерн в иконописи. http://www.raruss. ru/russe-moderne/3984-modernist-style-russian-icons.html (Аата обращения: 13.06.2019).

25. УАьяновський В. Аиво й Аива київського Володимирського собору. Київ: АибіАь, 2016. 432 с.: іА.

26. Коган А. 3. Врубель. URL: https://www.litmir.me/br/?b= 200516\&p=32 (Аата обращения: 13.06.2019).

27. Яремич С.Я. Михаил Александрович Врубель: Жизнь и творчество. Москва: ИзАание И. Кнебель, 1911. 208 с. 
Сторчай О.

Сакральний живопис Михайла Врубемя: Проблема канону (київський період творчості)

Анотація. Розглянуто сакральний живопис і проблему канону у творчості видатного російського художника польського похоАження (по батькові) Михайла Врубеля (1856-1910). Він мав величезний Аар художника-монументаліста, але розкрити свої зАібності на цьому терені в повну симу йому не судилося. АосвіА церковного живопису почався і закінчився Аля художника у так званий «київський періоА», який тривав Аише п'ять років (1884-1889).

Цей період є оАним із найважливіших у творчості М. Врубемя, коли не тільки визначияося коло основних тем і був вироблений неповторний врубелевський стиль живопису, але й створено низку видатних сакральних монументальних творів. Весь корпус сакрального живопису М. Врубеля складається з Авох частин: перша — реалізовані монументальні і станкові роботи художника, Аруга — твори, що залишимися тімьки в ескізах.

Розглядаючи два основні напрями, що склалися до кінця XIX століття в церковному живописі Російської імперії - неоруський стиль і модерн - автор відзначає особливу роль Врубеля у формуванні останнього.

У статті простежується, як через вивчення і дбайливе освоєння зразків давньоруського (XI століття), візантійського (VIXII століть) монументального мистецтва, італійського живопису епохи ВіАродження і своє особливе особисте світосприйняття М. Врубель виробляє протягом «київського періоду» живописний стиль, який є органічною частиною європейського варіанту стилю модерн.

Ключові слова: київський період творчості Михайла Врубеля, сакральний живопис, проблема канону.

\section{Сторчай О.В.}

\section{Сакральная живопись Михаила Врубемя: проблема канона (киевский период творчества)}

Аннотация. Рассмотрена сакральная живопись и проблема канона в творчестве выдающегося русского художника польского происхождения (по отцу) Михаила Врубеля (1856-1910). Он обкадал огромным даром художника-монументалиста, но раскрыть свои возможности на этом поприще в полную силу ему было не суждено. Опыт церковной живописи начался и закончился Аля художника в так называемый «киевский периоА», который Алился всего пять мет (1884-1889).

Этот период один из самих важных в творчестве М. Врубеля. Именно тогАа не только определился круг основных тем и сформировался неповторимый врубелевский стиль живописи, но и был создан ряА выдающихся сакральных монументальных произведений. Весь корпус сакральной живописи М. Врубеля состоит из Авух частей: первая — воплощенные монументальные и станковые произведения художника, вторая - работы, которые остались только в эскизах. Рассматривая два основных направления, сложившихся к концу XIX столетия в церковной живописи Российской империи - неорусский и стиль модерн автор отмечает особую роль Врубеля в формировании последнего.

В статье прослеживается, как на протяжении «киевского периода» через изучение и бережное освоение образцов Аревнерусского (ХI века), византийского (VI-XII веков) монументального искусства, итальянской живописи эпохи Возрождения и своего особого Аичного мировосприятия, М. Врубель вырабатывает живописный стиль, который явмяется органичной частью европейского варианта стиля модерн.

Ключевые слова: киевский период творчества Михаила Врубемя, сакральная живопись, проблема канона. 